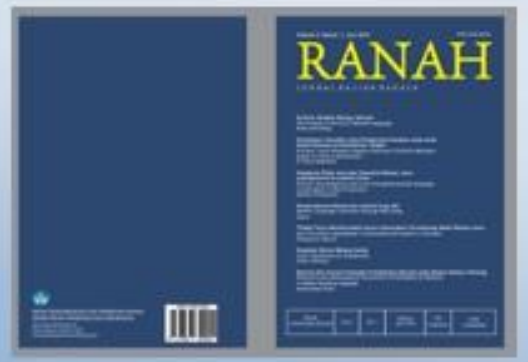

\title{
PENGETAHUAN MASYARAKAT SUNDA PEDESAAN KABUPATEN GARUT \\ DAN KABUPATEN CIANJUR JAWA BARAT \\ TENTANG PERATURAN KEBAHASAAN
}

The Knowledge of Rural Sundanese Societyin Garut

And Cianjur Regency, West Java

on Language Regulation

\section{Dindin Samsudin}

Balai Bahasa Jawa Barat

dins_samsoe75@yahoo.com

\begin{abstract}
Abstrak
Kenyataan kebahasaan yang ada di Indonesia masih saja memprihatinkan. Jika diamati, hingga kini masih banyak pemakaian bahasa di ruang publik, baik papan nama maupun papan petunjuk, yang menggunakan bahasa asing atau campuran bahasa Indonesia dan bahasa asing. Kenyataan kebahasaan tersebut tidak sesuai dengan peraturan perundang-undangan yang berlaku di Indonesia karena peraturan perundang-undangan mengharuskan pengutamaan penggunaan bahasa Indonesia dalam ranah publik. Namun, peraturan perundang-undangan tentang kebahasaan tersebut sepertinya belum diketahui oleh masyarakat sehingga mereka masih mengutamakan bahasa asing. Penelitian ini bertujuan untuk mengungkapkan pengetahuan masyarakat Sunda pedesaan di Kabupaten Garut dan Cianjur Jawa Barat tentang peraturan kebahasaan. Penelitian ini menggunakan pendekatan kuantitatif dengan metode survei. Hasil dari penelitian ini menunjukkan bahwa secara umum pengetahuan masyarakat Sunda pedesaan di Kabupaten Garut dan Cianjur di Jawa Barat tentang peraturan kebahasaan dapat dikategorikan tidak baik sebab rata-ratanya baru mencapai $34,25 \%$ dari ideal.
\end{abstract}

Kata-kata kunci: masyarakat Sunda, pedesaan, peraturan kebahasaan.

\begin{abstract}
The reality of the language usage that exists in Indonesia is still apprehensive. If we observed, until now there are so many language usages in public spaces, both billboards and instructional boards still use foreign languages or a mix between Indonesian language and foreign languages. That reality of language is not relevant with the legislations which prevail in Indonesia because the legislations stipulate the preferential using of Indonesian language in public space. However, the legislations about language are not well known by the society, so they still prefer using the foreign languages. This research aimed to reveal the knowledge of rural Sundanese society in Garut and Cianjur Regency, West Java about the language regulations. This research used quantitative approach with survey method. The result showed that in general the knowledge of rural Sundanese society in Garut and Cianjur Regency, West Java about language regulations can be categorized not good because the average value only reached $34.25 \%$ of the ideal standard. Keywords: language regulation, Sundanese society, rural areas.
\end{abstract}

How to Cite: Samsudin, Dindin. (2017). Pengetahuan Masyarakat Sunda Pedesaan Kabupaten Garut dan Kabupaten Cianjur Jawa Barat tentang Peraturan Kebahasaan. Ranah: Jurnal Kajian Bahasa, 6(2), 198219. doi: https://doi.org/10.26499/rnh.v6i2.257 


\section{PENDAHULUAN}

Kenyataan kebahasaan yang ada di Indonesia, khususnya di Jawa Barat, jika diamati, banyak pemakaian bahasa di ruang publik, baik papan nama maupun papan petunjuk, yang menggunakan bahasa asing atau campuran bahasa Indonesia dan bahasa asing. Sebagai contoh di Kabupaten Garut beberapa toko atau tempat usaha dinamai Neymar Shoes, Adison Sport, Smile Fashion, Kuple Toys, Modern Textile \& Tailor, dan Print Center. Kemudian, beberapa perumahan dinamai Karisma Residence, Bumi Malayu Regency, dan Permata Hijau Land.

Pada papan petunjuk umum di beberapa tempat pun digunakan in dan out dan jarang sekali digunakan 'keluar' dan 'masuk'. Contoh lainnya adalah lebih sering ditemukan meeting room dan welcome daripada 'ruang pertemuan' dan 'selamat datang' di beberapa hotel. Bahkan, lebih banyak ditemukan kata men dan women daripada 'pria' dan 'wanita' ketika kita akan memasuki kamar kecil di beberapa tempat umum.

Hal tersebut mengindikasikan kondisi penggunaan bahasa Indonesia belum diprioritaskan oleh masyarakat. Artinya, masyarakat Indonesia belum menyadari sepenuhnya makna memiliki bahasa sebagai kekayaan dan identitas bangsa. Sebagai upaya untuk menghindari hal tersebut dan menjadikan bahasa Indonesia sebagai bahasa yang bermartabat dan menciptakan kawasan tertib berbahasa, pemerintah sudah membuat peraturan perundang-undangan yang mengharuskan pengutamaan penggunaan bahasa Indonesia di ranah publik.

Beberapa peraturan tentang kebahasaan sudah ada di Indonesia, yaitu Undangundang Republik Indonesia Nomor 24 Tahun 2009 tentang Bendera, Bahasa, dan Lambang Negara, serta Lagu Kebangsaan; Peraturan Menteri Dalam Negeri Nomor 40 Tahun 2007 tentang Pedoman bagi Kepala Daerah dalam Pelestarian dan Pengembangan Bahasa Negara dan Bahasa Daerah, dan Peraturan Menteri Perdagangan Republik Indonesia Nomor 67/M-DAG/PER/11/2013 tentang Kewajiban Pencantuman Label dalam Bahasa Indonesia.

Walaupun peraturan tentang penggunaan bahasa Indonesia sudah ada, sikap masyarakat terhadap penggunaan bahasa Indonesia masih saja memprihatinkan. Masyarakat cenderung mempunyai sikap yang lebih positif terhadap bahasa asing daripada bahasa Indonesia. Masyarakat justru seperti mempunyai rasa bangga terhadap bahasa asing daripada bahasa Indonesia sebagai bahasa negara dan bahasa nasional. 
Penggunaan bahasa asing yang digunakan oleh masyarakat menunjukkan bahwa komponen psikomotorik (konatif) masyarakat kurang positif terhadap bahasa Indonesia. Patut ditelaah apakah komponen kognitif dan afektifnya juga kurang positif? Pemakaian bahasa di ruang publik oleh kelompok masyarakat tersebut tidak dapat dijadikan tolok ukur dalam berbahasa karena belum diketahui apakah mereka sudah mengetahui peraturan perundang-undangan yang mengatur penggunaan bahasa di ruang publik.

Berdasarkan hal tersebut, penelitian pengetahuan masyarakat tentang peraturan perundang-undangan yang mengatur penggunaan bahasa di ruang publik di kalangan pengguna bahasa Indonesia sangat menarik untuk dikaji.

Penelitian sikap bahasa sudah banyak dilakukan orang, baik ahli bahasa dari barat maupun dari Indonesia, di antaranya adalah sebagai berikut. Gunarwan (1983) dalam tulisannya yang berjudul "Reaksi Subjektif terhadap Bahasa Indonesia Baku dan Nonbaku" itu dapat membuktikan adanya sikap positif dari kalangan mahasiswa terhadap bahasa Indonesia baku. Sikap mahasiswa seperti itu akan berpengaruh terhadap sikap masyarakat yang lain terhadap penggunaan bahasa Indonesia baku.

Kajian sikap bahasa masyarakat juga di antaranya sudah dilakukan oleh Kartika et al. (2013) dan (2014), Sustiyanti dan Ratih Rahayu (2017), serta Kulsum et al. (2015). Dalam kajiannya Kartika et al. mendeskripsikan "Sikap Bahasa Masyarakat Jawa Barat terhadap Bahasa Daerah, Bahasa Indonesia, dan Bahasa Asing” (2013) dan "Sikap Bahasa Pejabat Publik di Lingkungan Kementerian Pendidikan dan Kebudayaan di Wilayah Jawa Barat terhadap Bahasa Daerah, Bahasa Indonesia, dan Bahasa Asing” (2014). Sustiyanti dan Ratih Rahayu (2017) mendeskripsikan "Pengaruh Pengetahuan tentang Peraturan Kebahasaan terhadap Sikap Bahasa Pengusaha Kuliner di Kabupaten Pringsewu." Sementara itu, Kulsum et al. (2015) dalam kajiannya mendeskripsikan tentang sikap bahasa para pengusaha/pengembang perumahan di empat kota dan kabupaten di wilayah Jawa Barat dan mengaitkan sikap bahasa mereka dengan pengetahuan mereka tentang peraturan kebahasaan. Dalam hasil penelitian Kulsum et al. ditunjukkan bahwa pengetahuan para pengusaha/pengembang perumahan di Jawa Barat terhadap peraturan kebahasaan termasuk ke dalam kategori kurang (37,38\%).

Dari penelitian sikap bahasa di Jawa Barat setakat ini, terlihat bahwa pada umumnya sikap masyarakat Jawa Barat termasuk ke dalam kategori baik terhadap bahasa daerah, bahasa Indonesia, dan negatif terhadap bahasa asing. Namun, pengetahuan masyarakat terhadap peraturan kebahasaan belum sepenuhnya terdeskripsikan. 
Penelitian pengetahuan masyarakat terhadap peraturan kebahasaan untuk kelompok masyarakat dipandang penting karena hasilnya dapat merefleksikan sikap bahasa masyarakat Sunda terhadap ketiga bahasa yang hidup di Jawa Barat. Hasil penelitian ini juga dapat dijadikan dasar bagi pengambilan keputusan kebijakan bahasa, baik yang berkaitan dengan bahasa daerah, bahasa Indonesia, maupun bahasa asing, di wilayah Jawa Barat.

Mengingat beragamnya kelompok masyarakat dan luasnya wilayah Jawa Barat, pengetahuan masyarakat di wilayah Jawa Barat terhadap peraturan kebahasaan dalam penelitian ini akan difokuskan pada kelompok masyarakat Sunda di wilayah pedesaan Kabupaten Garut dan Kabupaten Cianjur. Masalah yang dikaji dalam penelitian ini adalah bagaimana pengetahuan masyarakat Sunda di pedesaan di Jawa Barat tentang peraturan kebahasaan? Penelitian ini bertujuan untuk mengungkapkan pengetahuan masyarakat Sunda di pedesaan di Jawa Barat tentang peraturan kebahasaan.

\section{LANDASAN TEORI}

Teori sosiolinguistik berkaitan dengan teori sikap bahasa karena sosiolinguistik memandang bahasa sebagai suatu institusi sosial, baik individu maupun kelompok masyarakat yang melakukan interaksi sosial.

Hudson (1996) mengatakan bahwa sosiolinguistik mencakupi bidang kajian yang sangat luas, tidak hanya menyangkut wujud formal bahasa dan variasinya, tetapi juga penggunaan bahasa di masyarakat. Penggunaan bahasa tersebut mencakupi faktor kebahasaan dan faktor nonkebahasaan. Atas dasar itu, sosiolinguistik memandang suatu bahasa itu terdiri atas ragam-ragam yang terbentuk dari kelompok-kelompok sosial yang ada. Dengan demikian, dapat dipahami bahwa pada setiap kelompok masyarakat terdapat nilai-nilai sosial dan budaya yang khusus pada penggunaan bahasa mereka yang berbeda dengan kelompok masyarakat lainnya.

Sikap bahasa sebagai sebuah istilah adalah perilaku, gerak-gerik, dan perbuatan berlandaskan pendirian, pandangan, pendapat, dan keyakinan. Bahasa, baik bahasa daerah, bahasa nasional, maupun bahasa asing adalah alat komunikasi yang digunakan oleh penutur ataupun pemakai bahasa untuk mengutarakan kehendak, maksud, atau harapan agar dapat bekerja sama, berinteraksi, dan mengidentifikasikan diri. Jadi, sikap bahasa adalah suatu posisi mental atau perasaan terhadap bahasa sendiri atau bahasa orang lain (Ridwan, 2006:211). 
Sikap terdiri atas tiga unsur, yaitu unsur kognitif, afektif, dan konatif (psikomotorik). Unsur kognitif menyangkut masalah pengetahuan alam sekitar dan gagasan, yang kategorinya dipergunakan dalam proses berpikir. Unsur afektif berhubungan dengan masalah penilaian, baik suka atau tidak suka, terhadap suatu situasi. Apabila seseorang mempunyai rasa baik atau senang pada suatu situasi, orang tersebut dapat dikatakan mempunyai sikap positif, dan sebaliknya memiliki sikap negatif. Unsur konatif berhubungan dengan perilaku atau perbuatan seseorang dalam mengambil keputusan terakhir terhadap suatu keadaan. Perlu diperhatikan karena sikap dapat itu dapat positif atau negatif, sikap terhadap bahasa pun demikian (Lambert, 1976 dalam Chaer, 2010).

Spolsky (1998:149) menyatakan bahwa seseorang yang mempelajari suatu bahasa dilatarbelakangi oleh sikapnya terhadap bahasa yang dipelajarinya, serta meliputi (1) sikap terhadap tujuan praktis penggunaan bahasa target dan (2) sikap terhadap orang yang menggunakan bahasa target. Hal tersebut diperkuat oleh Batram (2010:34) yang menegaskan bahwa keterkaitan antara sikap pada pembelajaran bahasa dengan penguasaan berbahasa mungkin tidak seperti yang dibayangkan. Hal ini terjadi karena sikap tidak selalu mencerminkan perilaku atau penguasaan terhadap suatu hal.

Berdasarkan ulasan beberapa teori tadi, pengetahuan tentang peraturan kebahasaan yang akan diteliti erat kaitannya dengan sikap bahasa seseorang. Pengetahuan kebahasaan seseorang termasuk ke dalam unsur kognitif dalam sikap bahasa, seperti yang dikemukakan oleh Lambert.

Berkaitan dengan penggunaan bahasa Indonesia, Indonesia memiliki peraturan yang berkaitan dengan kebahasaan. Peraturan yang berkaitan dengan masalah kebahasaan di Indonesia tertulis dalam

1. Undang-Undang Dasar Republik Indonesia 1945, Pasal 36: Bahasa negara ialah bahasa Indonesia.

2. Undang-undang Republik Indonesia Nomor 24 Tahun 2009 tentang Bendera, Bahasa, dan Lambang Negara, serta Lagu Kebangsaan.

3. Peraturan Presiden Republik Indonesia Nomor 16 Tahun 2010 tentang Penggunaan Bahasa Indonesia dalam Pidato Resmi Presiden dan/atau Wakil Presiden serta Pejabat Negara Lainnya.

4. Peraturan Pemerintah Republik Indonesia, Nomor 57 Tahun 2014 tentang Pengembangan, Pembinaan, dan Perlindungan Bahasa dan Sastra, serta Peningkatan Fungsi Bahasa Indonesia.

5. Peraturan Menteri Dalam Negeri Nomor 40 Tahun 2007 tentang Pedoman bagi Kepala Daerah dalam Pelestarian dan Pengembangan Bahasa Negara dan Bahasa Daerah. 


\section{Peraturan Menteri Perdagangan Republik Indonesia Nomor 67/M-DAG/PER/} 11/2013, tentang Kewajiban Pencantuman Label dalam Bahasa Indonesia.

Walaupun begitu, penggunaaan bahasa Indonesia hingga kini masih kalah bersaing dengan bahasa asing. Terdapat beberapa faktor yang menyebabkan hilangnya rasa bangga terhadap bahasa sendiri, di antaranya adalah faktor politik, ras, etnik, dan gengsi. Mengingat adanya kecenderungan ketidaktahuan masyarakat, terutama masyarakat pedesaan tentang peraturan kebahasaan, fokus penelitian ini adalah pengetahuan masyarakat pedesaan di Jawa Barat.

Dalam peraturan perundang-undangan, Kementerian Dalam Negeri mendefinisikan desa sebagai berikut.

\section{(1) Undang-Undang Nomor 22 Tahun 1999}

Desa adalah kesatuan masyarakat hukum yang memiliki kewenangan untuk mengatur dan mengurus kepentingan masyarakat setempat berdasarkan asal-usul dan adat-istiadat setempat yang diakui dalam sistem pemerintahan nasional dan berada di daerah kabupaten.

(2) Undang-Undang Nomor 6 Tahun 2014

Desa adalah desa dan desa adat atau yang disebut dengan nama lain, selanjutnya disebut Desa, adalah kesatuan masyarakat hukum yang memiliki batas wilayah yang berwenang untuk mengatur dan mengurus urusan pemerintahan, kepentingan masyarakat setempat berdasarkan prakarsa masyarakat, hak asalusul, dan/atau hak tradisional yang diakui dan dihormati dalam sistem pemerintahan Negara Kesatuan Republik Indonesia.

Kemudian, Landis (1948) mendefinisikan desa (village) sebagai suatu wilayah yang penduduknya kurang dari 2.500 jiwa dengan ciri-ciri, yaitu 1) mempunyai pergaulan hidup yang saling mengenal; 2) adanya ikatan perasaan yang sama tentang kebiasaan; 3) cara berusaha bersifat agraris dan sangat dipengaruhi oleh faktor-faktor alam, misalnya iklim topografi, dan sumber daya alam.

Dalam penelitian kuantitatif, analisis data yang digunakan adalah statistik. Analisis statistik terdiri atas dua macam: statistik deskriptif dan statistik inferensial. Statistik deskriptif adalah statistik yang digunakan untuk menganalisis data dengan cara mendeskripsikan atau menggambarkan data yang telah terkumpul sebagaimana adanya tanpa bermaksud membuat kesimpulan yang berlaku untuk umum atau generalisasi (Sugiyono, 2010). 
Statistik deskriptif menggambarkan apa yang ditunjukkan oleh data. Hal ini digunakan untuk menunjukkan deskriptif kuantitatif dalam bentuk yang dapat dibaca dengan mudah (Widi, 2010). Widi menambahkan bahwa statistika deskriptif digunakan untuk menggambarkan ciri-ciri dasar dari data hasil penelitian dengan memberikan rangkuman sederhana tentang sampel dan ukuran. Analisis deskriptif kuantitatif disertai dengan grafik analisis sederhana, statistik deskriptif secara sederhana menggambarkan apa yang ditunjukkan oleh data (Widi, 2010). Sementara itu, Burhan Bungin mengatakan bahwa kuantitatif deskriptif yaitu penelitian kuantitatif yang bertujuan hanya menggambarkan keadaan gejala sosial apa adanya, tanpa melihat hubungan-hubungan yang ada (Bungin, 2001).

Berdasarkan uraian teori analisis data tadi, pengetahuan tentang peraturan kebahasaan masyarakat dapat dipaparkan dalam bentuk angka-angka, kemudian dideskripsikan agar lebih mudah ditangkap maknanya oleh siapa pun yang membutuhkan informasi.

\section{METODE PENELITIAN}

Pendekatan yang digunakan dalam penelitian ini berkaitan dengan pendekatan teoretis dan metodologis. Pendekatan teoretis mengacu pada pendekatan sosiolinguistik karena sosiolinguistik termasuk teori atau ilmu yang berkaitan dengan pemakaian bahasa dalam kaitan dengan masyarakat (Chaer, 2010:2). Sementara itu, pendekatan metodologis menggunakan pendekatan kuantitatif yang bersifat deskriptif, yaitu penafsiran data yang berkenaan dengan fakta, variabel, dan fenomena yang terjadi saat penelitian berlangsung dengan menyajikan data apa adanya.

Pengambilan data dalam penelitian ini menggunakan metode survei, yaitu mengambil sampel dari populasi dan mengumpulkan data melalui kuesioner sebagai alat pengumpul data yang pokok. Penerapan metode itu bertujuan untuk menggambarkan dan menafsirkan hal yang berkenaan dengan suatu kondisi atau gejala seperti apa adanya atau mendeskripsikan gejala faktual dan kaitan berbagai variabel masalah yang diteliti secara sistematis.

Karakteristik subjek penelitian ditinjau dari delapan aspek, yaitu1) usia; 2) pendidikan; 3) pekerjaan; 4) penghasilan; 5) jenis kelamin; 6) identitas penduduk; 7) frekuensi keluar daerah; dan 8) domisili. Sementara itu, sampel penelitian sebanyak 502 orang yang berasal dari Kabupaten Garut dan Kabupaten Cianjur. Materi kuesioner terdiri atas profil responden dan pertanyaan mengenai pengetahuan kebahasaan. 
Instrumen penelitian untuk profil responden sebanyak delapan pertanyaan. Sementara itu, variabel pengetahuan tentang peraturan kebahasaan berupa kuesioner sebanyak sepuluh pertanyaan.

Data yang digunakan adalah data yang diperoleh melalui penyebaran angket yang dibagikan kepada masyarakat pedesaan minimal berusia 17 tahun atau sudah menikah yang tinggal di Kabupaten Garut dan Cianjur. Angket tersebut dibagikan kepada 502 responden.

Data tersebut berpedoman pada Skala Likert untuk mengetahui sikap bahasa masyarakat pedesaan. Data yang diperoleh adalah data kuantitatif, yaitu data yang berupa angka-angka dari hasil pengukuran yang berupa pertanyaan yang terkait dengan pengetahuan perundang-undangan.

Setelah data terkumpul, data diolah dengan langkah-langkah sebagai berikut. Tahap pertama membuat tabulasi skor angket pengetahuan dan sikap bahasa masyarakat pedesaan dan tahap kedua membuat skor keseluruhan hasil tes. Data tersebut kemudian dianalis secara kuantitatif dilakukan berdasarkan jawaban-jawaban atas pertanyaan yang dilakukan dan diberi bobot berdasarkan skala Likert.

Prosedur analisis data dalam menginterpretasikan hasil pengolahan data, pendapat dari responden yang diperoleh dari hasil angket dibuat dalam bentuk kategori kualitatif: sangat baik, baik, cukup baik, kurang baik, dan tidak baik (Martadiputra, 2016).

Tahap terakhir adalah tahap uji statistik untuk mengetahui korelasi variabel. Pada tahap terakhir ini digunakan program komputer SPSS (Statistics Package for Social Scientist). Untuk melihat pengetahuan kebahasaan masyarakat pedesaan, data dianalisis dengan statistik deskriptif (crosstabulation).

\section{PEMBAHASAN}

Dalam menginterpretasikan hasil pengolahan data, pendapat dari responden yang diperoleh dari hasil angket dibuat dalam bentuk kategori kualitatif: Sangat Baik, Baik, Cukup Baik, Kurang Baik, dan Tidak Baik sesuai dengan yang tertuang dalam prosedur analisis data.

Dengan demikian, dalam menginterpretasikan hasil pengolahan data pengetahuan subjek penelitian tentang peraturan perundang-undangan yang berkaitan dengan bahasa mengacu pada Tabel 1 . 


\section{Tabel 1}

\section{Pedoman Penafsiran Rata-rata Skor (\%) Pengetahuan Peraturan Kebahasaan}

\begin{tabular}{lll}
\hline No. & Rata-rata Skor pengetahuan $(\boldsymbol{\%})$ & Kategori \\
\hline 1 & Rata-rata $\geq 84,00$ & Sangat Baik \\
\hline 2 & $68,00 \leq$ Rata-rata $<84,00$ & Baik \\
\hline 3 & $52,00 \leq$ Rata-rata $<68,00$ & Cukup baik \\
\hline 4 & $36,00 \leq$ Rata-rata $<52,00$ & Kurang baik \\
\hline 5 & Rata-rata $<36,00$ & Tidak Baik \\
\hline
\end{tabular}

Pengetahuan masyarakat Sunda pedesaan di Jawa Barat tentang peraturan kebahasaan ditinjau berdasarkan domisili disajikan dalam Tabel 2 dan Diagram 1.

Tabel 2

Deskripsi Pengetahuan Kebahasaan Berdasarkan Domisili

\begin{tabular}{llllll} 
Variabel & Domisili & $\mathbf{N}$ & Mean & $\begin{array}{l}\text { Std. } \\
\text { Deviation }\end{array}$ & Kategori \\
\hline $\begin{array}{l}\text { Pengetahuan } \\
\text { Kebahasaan }\end{array}$ & Garut & 280 & 32.01 & 8.76 & Tidak baik \\
\cline { 2 - 6 } & Cianjur & 222 & 37.67 & 14.38 & Kurang Baik \\
\cline { 2 - 6 } & Total & 502 & 34.52 & 11.91 & Tidak Baik \\
\hline
\end{tabular}

\section{Diagram 1

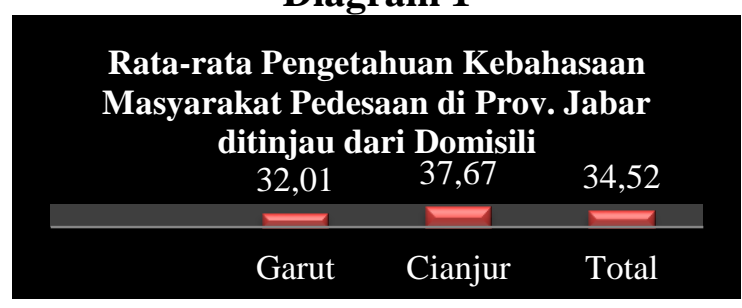 \\ Pengetahuan Kebahasaan Berdasarkan Domisili}

Dari Tabel 2 dan Diagram 1 terlihat bahwa:

1. Secara umum pengetahuan masyarakat Sunda pedesaan di Jawa Barat tentang peraturan kebahasaan ditinjau berdasarkan domisili rata-ratanya baru mencapai $34,52 \%$ sehingga termasuk kategori tidak baik.

2. Pengetahuan masyarakat Sunda di Garut Provinsi Jawa Barat tentang peraturan kebahasaan rata-ratanya baru mencapai $32,01 \%$ sehingga termasuk kategori tidak baik.

3. Pengetahuan masyarakat Sunda di Cianjur Provinsi Jawa Barat tentang peraturan kebahasaan rata-ratanya baru mencapai $37,67 \%$ sehingga termasuk kategori kurang baik.

Berdasarkan hal tersebut, pengetahuan masyarakat Sunda pedesaan di Jawa Barat tentang peraturan kebahasaan ditinjau berdasarkan domisili termasuk kategori tidak baik. Pengetahuan tentang peraturan kebahasaan masyarakat Sunda di Cianjur relatif lebih baik daripada di Garut. 


\section{Berdasarkan Jenis Kelamin}

Pengetahuan masyarakat Sunda pedesaan di Jawa Barat tentang peraturan kebahasaan ditinjau berdasarkan jenis kelamin disajikan dalam Tabel 3 dan Diagram 2.

Tabel 3

Deskripsi Pengetahuan Kebahasaan Berdasarkan Jenis Kelamin

\begin{tabular}{llllll}
\hline \multirow{2}{*}{ Variabel } & $\begin{array}{l}\text { Jenis } \\
\text { Kelamin }\end{array}$ & N & Mean & $\begin{array}{l}\text { Std. } \\
\text { Deviation }\end{array}$ & Kategori \\
\hline \multirow{2}{*}{$\begin{array}{l}\text { Pengetahuan } \\
\text { Kebahasaan }\end{array}$} & Laki-laki & 249 & 34.59 & 12.25 & Tidak Baik \\
\cline { 2 - 6 } & Perempuan & 253 & 34.44 & 11.59 & Tidak Baik \\
\cline { 2 - 6 } & Total & 502 & 34.52 & 11.91 & Tidak Baik \\
\hline
\end{tabular}

\section{Diagram 2}

Rata-rata Pengetahuan Kebahasaan Masyarakat Pedesaan di Prov. Jabar Ditinjau dari Jenis Kelamin $\begin{array}{lll}34,59 & 34,44 & 34,52\end{array}$

Laki-laki Perempuan Total

\section{Pengetahuan Kebahasaan Berdasarkan Jenis Kelamin}

Dari Tabel 3 dan Diagram 2 menunjukkan hal berikut.

1. Secara umum pengetahuan masyarakat Sunda pedesaan di Jawa Barat tentang peraturan kebahasaan ditinjau berdasarkan jenis kelamin rata-ratanya baru mencapai 34,52\% sehingga termasuk kategori tidak baik.

2. Pengetahuan masyarakat Sunda pedesaan berjenis kelamin laki-laki di Provinsi Jawa Barat tentang peraturan kebahasaan rata-ratanya baru mencapai 34,59\% sehingga termasuk kategori tidak baik.

3. Pengetahuan masyarakat Sunda pedesaan yang berjenis kelamin perempuan di Provinsi Jawa Barat tentang peraturan kebahasaan rata-ratanya mencapai 34,44\% juga termasuk kategori tidak baik.

Berdasarkan hal tersebut, pengetahuan masyarakat Sunda pedesaan di Jawa Barat tentang peraturan kebahasaan ditinjau berdasarkan jenis kelamin termasuk kategori tidak baik. Pengetahuan tentang peraturan kebahasaan masyarakat Sunda yang berjenis kelamin laki-laki relatif lebih baik dibanding yang berjenis kelamin perempuan. 


\section{Berdasarkan Tingkat Pendidikan}

Pengetahuan masyarakat Sunda pedesaan di Jawa Barat tentang peraturan kebahasaan ditinjau berdasarkan tingkat pendidikan disajikan dalam Tabel 4 dan Diagram 3.

\section{Tabel 4}

\section{Deskripsi Pengetahuan Kebahasaan Berdasarkan Tingkat Pendidikan}

\begin{tabular}{llllll}
\hline \multirow{2}{*}{ Variabel } & Pendidikan & N & Mean & $\begin{array}{l}\text { Std. } \\
\text { Deviation }\end{array}$ & Kategori \\
\hline \multirow{2}{*}{$\begin{array}{lllll}\text { Pengetahuan } \\
\text { Kebahasaan }\end{array}$} & SLTP & 152 & 30.33 & 4.64 & Tidak Baik \\
\cline { 2 - 6 } & SLTA & 151 & 33.95 & 8.86 & Tidak Baik \\
\cline { 2 - 6 } & S1 & 77 & 44.39 & 19.75 & Kurang Baik \\
\cline { 2 - 6 } & Sidak sekolah & 4 & 29.32 & 0.00 & Tidak Baik \\
\cline { 2 - 6 } & Total & 502 & 34.52 & 11.91 & Tidak Baik \\
\hline
\end{tabular}

\section{Diagram 3}

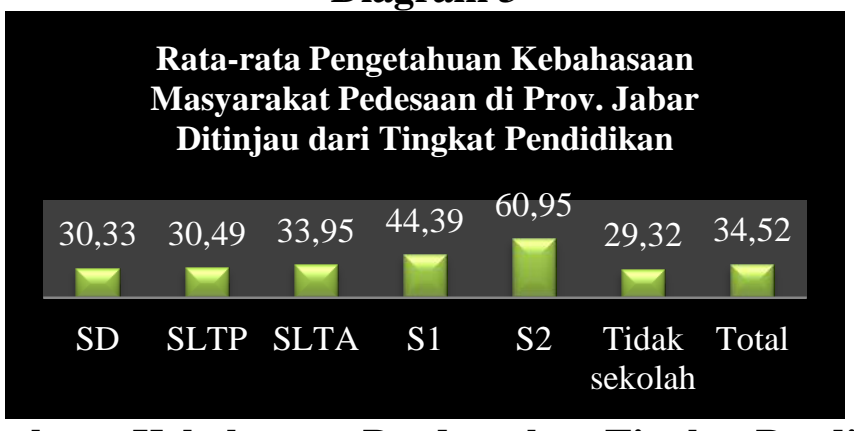

\section{Pengetahuan Kebahasaan Berdasarkan Tingkat Pendidikan}

Dari Tabel 4 dan Diagram 3 menunjukkan hal berikut.

1. Secara umum pengetahuan masyarakat Sunda pedesaan di Jawa Barat tentang peraturan kebahasaan ditinjau berdasarkan tingkat pendidikan rata-ratanya baru mencapai 34,52\% sehingga termasuk kategori tidak baik.

2. Pengetahuan masyarakat Sunda pedesaan di Jawa Barat yang berpendidikan SD tentang peraturan kebahasaan rata-ratanya baru mencapai 30,33\% termasuk kategori tidak baik.

3. Pengetahuan masyarakat Sunda pedesaan di Jawa Barat yang berpendidikan SLTP tentang peraturan kebahasaan rata-ratanya mencapai 30,49\% sehingga termasuk kategori tidak baik. 
4. Pengetahuan masyarakat Sunda yang berpendidikan SLTA di Provinsi Jawa Barat tentang peraturan kebahasaan rata-ratanya baru mencapai 33,95\% sehingga termasuk kategori tidak baik.

5. Pengetahuan masyarakat Sunda pedesaan di Jawa Barat yang berpendidikan S-1 tentang peraturan kebahasaan rata-ratanya baru mencapai 44,39\% termasuk kategori kurang baik.

6. Pengetahuan tentang peraturan kebahasaan masyarakat Sunda pedesaan di Jawa Barat yang berpendidikan S-2 rata-ratanya mencapai $60,95 \%$ sehingga sudah termasuk kategori cukup baik.

7. Pengetahuan masyarakat Sunda pedesaan di Jawa Barat yang tidak sekolah tentang peraturan kebahasaan rata-ratanya mencapai $29,32 \%$ termasuk kategori tidak baik.

Berdasarkan hal tersebut, pengetahuan masyarakat Sunda pedesaan di Jawa Barat tentang peraturan kebahasaan ditinjau berdasarkan tingkat pendidikan termasuk kategori tidak baik. Pengetahuan masyarakat Sunda pedesaan di Jawa Barat yang tidak sekolah tentang peraturan kebahasaan lebih rendah dibanding yang berpendidikan SD.

Kemudian, pengetahuan masyarakat Sunda pedesaan tentang peraturan yang berpendidikan SD lebih rendah dibandingkan dengan yang berpendidikan SLTP. Sementara itu, pengetahuan masyarakat Sunda pedesaan di Jawa Barat yang berpendidikan SLTP tentang peraturan kebahasaan lebih rendah dibanding masyarakat yang berpendidikan SLTA. Pengetahuan masyarakat Sunda pedesaan di Jawa Barat yang berpendidikan SLTA tentang peraturan kebahasaan jauh lebih rendah dibanding yang berpendidikan S-1.

Selanjutnya, pengetahuan masyarakat Sunda pedesaan yang berpendidikan S-1 lebih rendah dibanding masyarakat Sunda pedesaan yang berpendidikan S-2. Berdasarkan hal tersebut, dapat disimpulkan bahwa semakin tinggi tingkat pendidikan masyarakat Sunda pedesaan yang ada di Jawa Barat semakin mengetahui peraturan tentang kebahasaan.

\section{Berdasarkan Usia}

Pengetahuan masyarakat Sunda pedesaan di Jawa Barat tentang peraturan kebahasaan ditinjau berdasarkan usia disajikan dalam Tabel 5 dan Diagram 4. 
Tabel 5

Deskripsi Pengetahuan Kebahasaan Berdasarkan Usia

\begin{tabular}{llllll}
\hline \multirow{2}{*}{ Variabel } & Usia & N & Mean & $\begin{array}{l}\text { Std. } \\
\text { Deviation }\end{array}$ & Kategori \\
\hline \multirow{3}{*}{$\begin{array}{l}\text { Pengetahuan } \\
\text { Kebahasaan }\end{array}$} & $<=30$ tahun & 36 & 29.32 & 0.00 & Tidak Baik \\
\cline { 2 - 6 } & $31-40$ tahun & 208 & 34.30 & 12.66 & Tidak Baik \\
\cline { 2 - 6 } & $41-50$ tahun & 200 & 34.83 & 10.22 & Tidak Baik \\
\cline { 2 - 6 } & $>50$ tahun & 58 & 37.41 & 16.56 & Kurang Baik \\
\cline { 2 - 6 } & Total & 502 & 34.52 & 11.91 & Tidak Baik \\
\hline
\end{tabular}

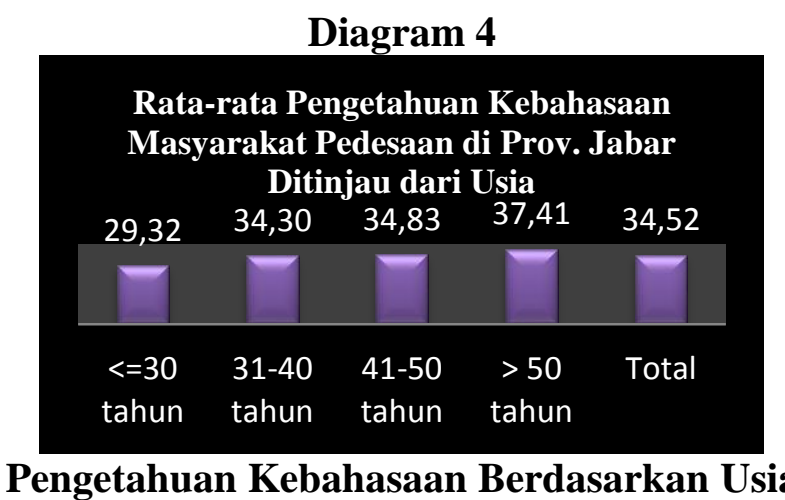

Dari Tabel 5 dan Diagram 4 menunjukkan hal berikut.

1. Secara umum pengetahuan masyarakat Sunda pedesaan di Jawa Barat tentang peraturan kebahasaan ditinjau berdasarkan usia rata-ratanya baru mencapai 34,52\% sehingga termasuk kategori tidak baik.

2. Pengetahuan masyarakat Sunda pedesaan di Jawa Barat yang berusia $<30$ tahun tentang peraturan kebahasaan rata-ratanya baru mencapai $29,32 \%$ termasuk kategori tidak baik.

3. Pengetahuan masyarakat Sunda pedesaan di Jawa Barat yang berusia $31-40$ tahun tentang peraturan kebahasaan rata-ratanya mencapai 34,30\% juga termasuk kategori tidak baik.

4. Pengetahuan masyarakat pedesaan yang berusia $41-50$ tahun di Jawa Barat tentang peraturan kebahasaan rata-ratanya mencapai 34,83\% termasuk kategori tidak baik.

5. Pengetahuan masyarakat Sunda pedesaan yang berusia $>50$ tahun di Jawa Barat tentang peraturan kebahasaan rata-ratanya mencapai $37,41 \%$ termasuk katagori kurang baik.

Berdasarkan hal tersebut, pengetahuan masyarakat Sunda pedesaan di Jawa Barat tentang peraturan kebahasaan ditinjau berdasarkan usia termasuk kategori tidak baik. Pengetahuan tentang peraturan kebahasaan masyarakat Sunda yang berusia > 50 tahun rata-ratanya relatif lebih baik dibanding masyarakat yang berusia $41-50$ tahun, usia $31-$ 
40, bahkan lebih baik dibanding yang berumur $<30$ tahun. Berdasarkan hal tersebut, dapat disimpulkan bahwa semakian tua usia masyarakat Sunda pedesaan yang ada di Jawa Barat semakin mengetahui peraturan tentang kebahasaan.

\section{Berdasarkan Pekerjaan}

Pengetahuan masyarakat Sunda pedesaan di Jawa Barat tentang peraturan kebahasaan ditinjau berdasarkan pekerjaan disajikan dalam Tabel 6 dan Diagram 5.

Tabel 6

Deskripsi Pengetahuan Kebahasaan Berdasarkan Pekerjaan

\begin{tabular}{llllll}
\hline \multirow{2}{*}{ Variabel } & Pekerjaan & N & Mean & $\begin{array}{l}\text { Std. } \\
\text { Deviation }\end{array}$ & Kategori \\
\hline \multirow{2}{*}{$\begin{array}{llllll}\text { Pengetahuan } \\
\text { Kebahasaan }\end{array}$} & PNS & 68 & 48.60 & 19.18 & Kurang Baik \\
\cline { 2 - 6 } & TNI/POLRI & 11 & 47.16 & 14.52 & Kurang Baik \\
\cline { 2 - 6 } & Swasta & 33 & 34.27 & 12.42 & Tidak Baik \\
\cline { 2 - 6 } & Buruh Tani & 38 & 29.32 & 0.00 & Tidak Baik \\
\cline { 2 - 6 } & Buruh Pabrik & 9 & 32.85 & 8.27 & Tidak Baik \\
\cline { 2 - 6 } & Ibu Rumah Tangga & 184 & 31.68 & 6.53 & Tidak Baik \\
\cline { 2 - 6 } & Petani & 24 & 30.67 & 3.29 & Tidak Baik \\
\cline { 2 - 6 } & Pensiunan & 1 & 29.32 & & Tidak Baik \\
\cline { 2 - 6 } & Total & 502 & 34.52 & 11.91 & Tidak Baik \\
\hline
\end{tabular}

\section{Diagram 5}

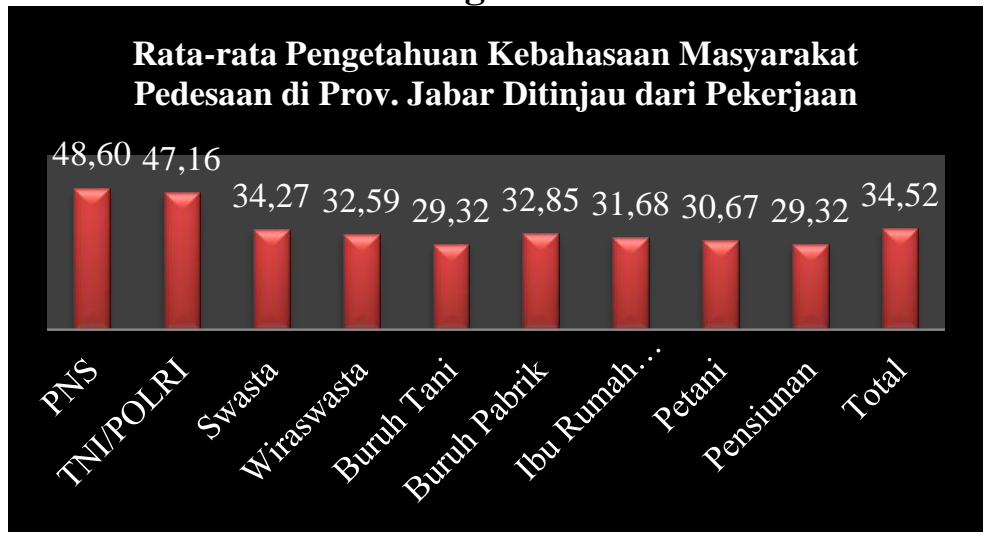

Pengetahuan Kebahasaan Berdasarkan Pekerjaan

Dari Tabel 6 dan Diagram 5 menunjukkan hal berikut.

1. Secara umum pengetahuan masyarakat Sunda pedesaan di Jawa Barat tentang peraturan kebahasaan ditinjau berdasarkan pekerjaan rata-ratanya baru mencapai $34,52 \%$ sehingga termasuk kategori tidak baik. 
2. Pengetahuan masyarakat Sunda pedesaan di Jawa Barat yang berprofesi sebagai PNS tentang peraturan kebahasaan rata-ratanya mencapai 48,60\% termasuk kategori kurang baik.

3. Pengetahuan tentang peraturan kebahasaan masyarakat Sunda pedesaan di Jawa Barat yang berprofesi sebagai TNI/POLRI rata-ratanya baru mencapai 47,16\% juga termasuk kategori kurang baik.

4. Pengetahuan tentang peraturan kebahasaan masyarakat Sunda pedesaan di Jawa Barat yang profesinya swasta rata-ratanya mencapai 34,27\% termasuk kategori tidak baik.

5. Pengetahuan tentang peraturan kebahasaan masyarakat Sunda pedesaan yang profesinya wiraswasta rata-ratanya mencapai $32,59 \%$ termasuk katagori tidak baik.

6. Pengetahuan tentang peraturan kebahasaan masyarakat Sunda pedesaan yang pekerjaannya buruh tani rata-ratanya 29,32\% termasuk kategori tidak baik.

7. Pengetahuan tentang peraturan kebahasaan masyarakat Sunda pedesaan yang pekerjaannya buruh pabrik rata-ratanya $32,85 \%$ termasuk kategori tidak baik.

8. Pengetahuan tentang peraturan kebahasaan masyarakat Sunda pedesaan yang pekerjaannya ibu rumah tangga rata-ratanya $31,68 \%$ termasuk kategori tidak baik.

9. Pengetahuan tentang peraturan kebahasaan masyarakat Sunda pedesaan yang pekerjaannya sebagai petani rata-ratanya $30,67 \%$ termasuk kategori tidak baik.

10. Pengetahuan tentang peraturan kebahasaan masyarakat Sunda pedesaan yang sudah pensiun rata-ratanya $29,32 \%$ termasuk kategori tidak baik.

Berdasarkan uraian tersebut, pengetahuan masyarakat Sunda pedesaan di Jawa Barat tentang peraturan kebahasaan ditinjau berdasarkan pekerjaan termasuk kategori tidak baik. Pengetahuan masyarakat Sunda pedesaan di Jawa Barat yang berprofesi sebagai PNS tentang peraturan kebahasaan masyarakat lebih baik dibanding yang berprofesi sebagai TNI/POLRI.

Sementara itu, pengetahuan tentang peraturan kebahasaan masyarakat yang berprofesi sebagai TNI/POLRI lebih baik dibanding yang berprofesi sebagai pegawai swasta. Lalu, pengetahuan tentang peraturan kebahasaan masyarakat yang berprofesi sebagai pegawai swasta lebih baik dibanding dengan yang pekerjaannya wiraswasta dan buruh pabrik.

Kemudian, pengetahuan tentang kebahasaan masyarakat yang pekerjaanya wiraswasta dan buruh pabrik lebih baik dibanding dengan ibu rumah tangga dan petani. 
Pengetahuan tentang peraturan kebahasaan masyarakat yang bekerja sebagai petani dan ibu rumah tangga lebih baik dibanding dengan masyarakat yang sudah pensiun dan yang bekerja sebagai buruh tani.

Berdasarkan hal tersebut dapat disimpulkan bahwa masyarakat yang berprofesi sebagai PNS lebih mengetahui tentang peraturan kebahasaan dibandingkan dengan yang berprofesi sebagai TNI/POLRI, pegawai swasta, wiraswasta, buruh pabrik, ibu rumah tangga, petani, buruh tani, dan pensiunan.

\section{Berdasarkan Penghasilan}

Pengetahuan masyarakat Sunda pedesaan di Jawa Barat tentang peraturan kebahasaan ditinjau berdasarkan penghasilan disajikan dalam Tabel 7 dan Diagram 6.

Tabel 7

Deskripsi Pengetahuan Kebahasaan Berdasarkan Penghasilan

\begin{tabular}{llllll} 
Variabel & Penghasilan & N & Mean & $\begin{array}{l}\text { Std. } \\
\text { Deviation }\end{array}$ & Kategori \\
\hline \multirow{3}{*}{$\begin{array}{c}\text { Pengetahuan } \\
\text { Kebahasaan }\end{array}$} & $<1$ juta & 272 & 31.10 & 5.77 & Tidak Baik \\
\cline { 2 - 6 } & $1-2$ juta & 127 & 33.46 & 10.51 & Tidak Baik \\
\cline { 2 - 6 } & $>2$ juta & 103 & 44.84 & 18.22 & Kurang Baik \\
\cline { 2 - 6 } & Total & 502 & 34.52 & 11.91 & Tidak Baik \\
\hline
\end{tabular}

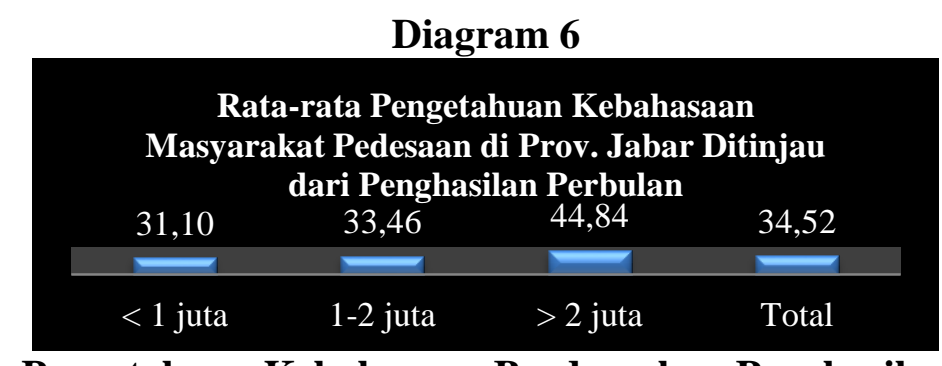

Pengetahuan Kebahasaan Berdasarkan Penghasilan

Dari Tabel 7 dan Diagram 6 menunjukkan hal berikut.

1. Secara umum pengetahuan masyarakat Sunda pedesaan di Jawa Barat tentang peraturan kebahasaan ditinjau berdasarkan penghasilan per bulan rata-ratanya baru mencapai 34,52\% sehingga termasuk kategori tidak baik.

2. Pengetahuan masyarakat Sunda pedesaan di Jawa Barat yang berpenghasilan $<1$ juta per bulan tentang peraturan kebahasaan rata-ratanya baru mencapai 31,10\% termasuk kategori tidak baik. 
3. Pengetahuan tentang peraturan kebahasaan masyarakat Sunda pedesaan yang berpenghasilan $1-2$ juta per bulan rata-ratanya mencapai $33,46 \%$ juga termasuk tidak baik.

4. Pengetahuan tentang kebahasaan masyarakat Sunda pedesaan di Jawa Barat yang penghasilannya $>2$ juta per bulan pun rata-ratanya hanya $44,84 \%$ termasuk kategori kurang baik.

Berdasarkan hal tersebut, pengetahuan tentang kebahasaan masyarakat Sunda pedesaan di Jawa Barat ditinjau berdasarkan penghasilan nilai rata-ratanya termasuk kategori tidak baik. Pengetahuan tentang kebahasaan masyarakat Sunda pedesaan di Jawa Barat yang berpenghasilan $>2$ juta per bulan rata-ratanya lebih tinggi dibanding dengan masyarakat yang berpenghasilan $1-2$ juta per bulan.

Sementara itu, pengetahuan tentang kebahasaan masyarakat yang berpenghasilan 1-2 juta per bulan rata-ratanya lebih tinggi dibanding dengan masyarakat yang berpenghasilan $<1$ juta per bulan. Simpulannya, semakin besar penghasilan masyarakat Sunda pedesaan yang ada di Jawa Barat semakin mengetahui peraturan tentang kebahasaan.

\section{Berdasarkan Identitas Penduduk}

Pengetahuan masyarakat Sunda pedesaan di Jawa Barat tentang peraturan kebahasaan ditinjau berdasarkan identitas penduduk disajikan dalam Tabel 8 dan Diagram 7.

\section{Tabel 8}

Deskripsi Pengetahuan Kebahasaan Berdasarkan Identitas Penduduk

\begin{tabular}{llllll}
\hline Variabel & Identitas Penduduk & N & Mean & $\begin{array}{l}\text { Std. } \\
\text { Deviation }\end{array}$ & Kategori \\
\hline \multirow{2}{*}{$\begin{array}{l}\text { Pengetahuan } \\
\text { Kebahasaan }\end{array}$} & Penduduk asli & 448 & 34.61 & 12.14 & Tidak Baik \\
\cline { 2 - 6 } & Penduduk Pendatang & 54 & 33.70 & 9.85 & Tidak Baik \\
\cline { 2 - 6 } & Total & 502 & 34.52 & 11.91 & Tidak Baik \\
\hline
\end{tabular}

\section{Diagram 7}

Rata-rata Pengetahuan Kebahasaan Masyarakat Pedesaan di Prov. Jabar Ditinjau dari Identitas Penduduk

34,61

33,70

Penduduk asli Penduduk Pendatang
34,52

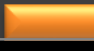

Total 
Dari Tabel 8 dan Diagram 7 menunjukkan hal berikut.

1. Secara umum pengetahuan masyarakat Sunda pedesaan di Jawa Barat tentang peraturan kebahasaan ditinjau berdasarkan identitas kependudukan rata-ratanya baru mencapai 34,52\% sehingga termasuk kategori tidak baik.

2. Pengetahuan masyarakat penduduk asli Sunda yang ada di Jawa Barat tentang peraturan kebahasaan rata-ratanya mencapai $34,61 \%$ termasuk kategori tidak baik.

3. Pengetahuan masyarakat Sunda pendatang yang ada di Provinsi Jawa Barat tentang peraturan kebahasaan rata-ratanya mencapai 33,70\% juga termasuk kategori tidak baik.

Berdasarkan uraian tadi, pengetahuan masyarakat Sunda pedesaan di Jawa Barat tentang peraturan kebahasaan ditinjau berdasarkan identitas kependudukan termasuk kategori tidak baik. Pengetahuan tentang peraturan kebahasaan masyarakat penduduk asli Sunda relatif lebih baik daripada masyarakat pendatang yang ada di Jawa Barat.

\section{Berdasarkan Frekuensi Bepergian Keluar Daerah}

Pengetahuan masyarakat Sunda pedesaan di Jawa Barat tentang peraturan kebahasaan ditinjau berdasarkan frekuensi bepergian keluar daerah disajikan dalam Tabel 9 dan Diagram 8.

\section{Tabel 9}

Deskripsi Pengetahuan Kebahasaan Berdasarkan Frekuensi Bepergian Keluar Daerah

\begin{tabular}{llllll}
\hline \multirow{2}{*}{ Variabel } & Frekuensi Keluar Daerah & N & Mean & $\begin{array}{l}\text { Std. } \\
\text { Deviation }\end{array}$ & Kategori \\
\hline & Tidak pernah & 133 & 31.13 & 5.71 & Tidak Baik \\
\cline { 2 - 6 } & Sekali dalam 2-10 tahun & 19 & 33.30 & 7.13 & Tidak Baik \\
\cline { 2 - 6 } $\begin{array}{l}\text { Pengetahuan } \\
\text { Kebahasaan }\end{array}$ & Sekali dalam 1 tahun & 113 & 33.09 & 9.31 & Tidak Baik \\
\cline { 2 - 6 } & sekali dalam lebih dari 6 bulan & \multirow{2}{*}{106} & 38.76 & 17.44 & Kurang Baik \\
\cline { 2 - 6 } & sekali dalam 1 bulan & 131 & 35.93 & 12.49 & Tidak Baik \\
\cline { 2 - 6 } & Total & 502 & 34.52 & 11.91 & Tidak Baik \\
\hline
\end{tabular}


Diagram 8

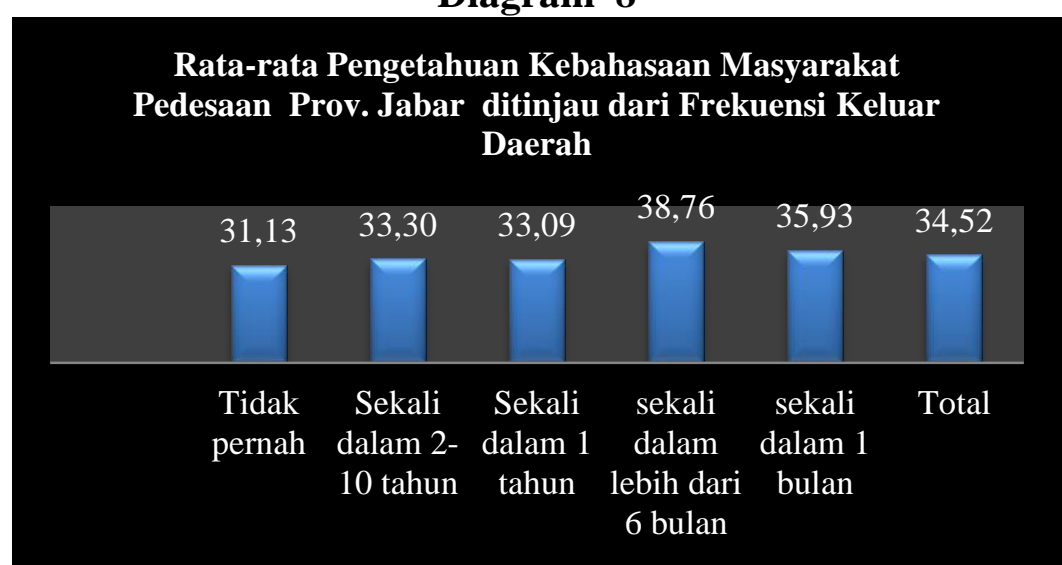

\section{Pengetahuan Kebahasaan Berdasarkan Frekuensi Bepergian Keluar Daerah}

Dari Tabel 9 dan Diagram 8 menunjukkan hal berikut.

1. Secara umum pengetahuan masyarakat Sunda pedesaan di Jawa Barat tentang peraturan kebahasaan ditinjau berdasarkan frekuensi keluar daerah rata-ratanya baru mencapai 34,52\% sehingga termasuk kategori tidak baik.

2. Pengetahuan masyarakat Sunda pedesaan di Jawa Barat yang tidak pernah keluar daerah tentang peraturan kebahasaan rata-ratanya mencapai 31,13\% termasuk kategori tidak baik.

3. Pengetahuan masyarakat Sunda pedesaan di Jawa Barat yang frekuensi keluar daerahnya sekali dalam 2-10 tahun tentang peraturan kebahasaan rata-ratanya mencapai 33,30\% termasuk kategori tidak baik.

4. Pengetahuan masyarakat Sunda pedesaan di Jawa Barat yang frekuensi keluar daerahnya sekali dalam satu tahun tentang peraturan kebahasaan rata-ratanya mencapai 33,09\% termasuk kategori tidak baik.

5. Pengetahuan masyarakat Sunda pedesaan di Jawa Barat yang frekuensi keluar daerahnya sekali dalam lebih dari enam bulan rata-ratanya mencapai 38,76\% termasuk kategori kurang baik.

6. Pengetahuan masyarakat Sunda pedesaan di Jawa Barat yang frekuensi keluar daerahnya sekali dalam satu bulan rata-ratanya mencapai 35,93\% termasuk kategori tidak baik.

Berdasarkan uraian data tadi, pengetahuan masyarakat Sunda pedesaan di Jawa Barat tentang peraturan kebahasaan ditinjau berdasarkan frekuensi keluar daerah termasuk kategori tidak baik. Pengetahuan masyarakat Sunda pedesaan di Jawa Barat yang frekuensi keluar kotanya sekali dalam enam bulan lebih baik dibanding dengan 
masyarakat Sunda pedesaan yang frekuensi keluar daerahnya sekali dalam satu bulan. Sementara itu, pengetahuan masyarakat Sunda pedesaan yang frekuensi keluar daerahnya sebulan sekali tentang peraturan kebahasaannya lebih baik dibanding dengan masyarakat yang frekuensi keluar daerahnya sekali dalam 2-10 tahun. Selanjutnya, pengetahuan masyarakat Sunda pedesaan yang frekuensi keluar daerahnya 2-10 tahun sekali tentang peraturan kebahasaannya lebih baik dibanding dengan masyarakat yang frekuensi keluar daerahnya setahun sekali.

Kemudian, pengetahuan masyarakat Sunda pedesaan yang frekuensi keluar daerahnya setahun sekali tentang peraturan kebahasaannya lebih baik dibanding dengan masyarakat yang tidak pernah keluar daerah. Jadi, masyarakat yang frekuensi keluar daerahnya sekali dalam enam bulan, pengetahuan tentang peraturan kebahasaannya relatif lebih baik dibanding dengan masyarakat yang tidak pernah keluar daerah, keluar daerahnya satu tahun sekali, 2-10 tahun sekali, bahkan lebih baik dari masyarakat yang tidak keluar daerahnya sebulan sekali.

\section{PENUTUP}

Pemakaian bahasa di ruang publik oleh kelompok masyarakat tidak dapat dijadikan tolok ukur sikap masyarakat dalam berbahasa karena belum diketahui apakah mereka sudah mengetahui peraturan perundang-undangan yang mengatur penggunaan bahasa di ruang publik. Dari hasil dan pembahasan dapat diketahui bahwa pengetahuan masyarakat Sunda pedesaan di Kabupaten Garut dan Kabupaten Cianjur, Jawa Barat tentang peraturan kebahasaan dapat dikategorikan tidak baik sebab rata-ratanya baru mencapai 34,25\% dari ideal. Secara umum pengetahuan masyarakat Sunda pedesaan di Kabupaten Garut dan Kabupaten Cianjur, Jawa Barat tentang peraturan kebahasaan ditinjau berdasarkan domisili rata-ratanya baru mencapai $34,52 \%$ sehingga termasuk kategori tidak baik.

Pengetahuan masyarakat Sunda pedesaan di Kabupaten Garut dan Kabupaten Cianjur, Jawa Barat tentang peraturan kebahasaan ditinjau berdasarkan jenis kelamin rataratanya baru mencapai 34,52\% sehingga termasuk kategori tidak baik. Berikutnya, ditinjau berdasarkan tingkat pendidikan, pengetahuan masyarakat Sunda pedesaan di Kabupaten Garut dan Kabupaten Cianjur, Jawa Barat tentang peraturan kebahasaan rataratanya baru mencapai $34,52 \%$ sehingga termasuk kategori tidak baik. 
Kemudian, secara umum pengetahuan masyarakat Sunda pedesaan di Kabupaten Garut dan Kabupaten Cianjur, Jawa Barat tentang peraturan kebahasaan ditinjau berdasarkan usia rata-ratanya baru mencapai 34,52\% sehingga termasuk kategori tidak baik. Sementara itu, ditinjau berdasarkan pekerjaan rata-ratanya, secara umum pengetahuan masyarakat Sunda pedesaan di Kabupaten Garut dan Kabupaten Cianjur, Jawa Barat tentang peraturan kebahasaan baru mencapai 34,52\% sehingga termasuk kategori tidak baik.

Selanjutnya, secara umum pengetahuan masyarakat Sunda pedesaan di Kabupaten Garut dan Kabupaten Cianjur di Jawa Barat tentang peraturan kebahasaan ditinjau berdasarkan penghasilan per bulan rata-ratanya baru mencapai 34,52\% sehingga termasuk kategori tidak baik. Lalu, ditinjau berdasarkan identitas kependudukan secara umum pengetahuan masyarakat Sunda pedesaan di Kabupaten Garut dan Kabupaten Cianjur, Jawa Barat tentang peraturan kebahasaan rata-ratanya baru mencapai 34,52\% sehingga termasuk kategori tidak baik. Terakhir, secara umum pengetahuan masyarakat Sunda pedesaan di Jawa Barat tentang peraturan kebahasaan ditinjau berdasarkan frekuensi keluar daerah rata-ratanya baru mencapai 34,52\% sehingga termasuk kategori tidak baik.

Oleh karena itu, peraturan perundang-undangan kebahasaan harus terus disosialisasikan kepada seluruh lapisan masyarakat di Indonesia. Selain itu, gerakan nasional akan kesadaran dan sikap positif masyarakat terhadap bahasa Indonesia perlu terus ditingkatkan. Pengembangan sikap positif adalah suatu langkah dan upaya dalam pembinaan dan pengembangan sikap dan rasa bangga dalam memiliki dan menggunakan bahasa Indonesia.

Penelitian untuk lapisan masyarakat yang lain perlu juga dilakukan untuk mengetahui secara umum pengetahuan masyarakat tentang peraturan kebahasaan. Hasil penelitian tersebut nantinya dapat dibandingkan dengan hasil penelitian yang diperoleh dari masyarakat pedesaan ini.

\section{DAFTAR PUSTAKA}

Batram, B. (2010). Attitudes to Modern Foreign Language Learning: Insights from Comparative Education. London: Continuum International Publishing Group.

Bungin, Burhan (2001). Metodologi Penelitian Sosial: Format-format Kuantitatif dan Kualitatif. Surabaya: Airlangga University Press.

Chaer, A. dan L.A. (2010). Sosiolinguistik: Perkenalan Awal. Jakarta: PT Rineka Cipta. 
Gunarwan, Asim. (1983). "Reaksi Subjektif terhadap Bahasa Indonesia Baku dan Nonbaku: Sebuah Pengkajian Sikap Bahasa". Makalah yang disampaikan dalam Kongres Bahasa Indonesia IV di Jakarta.

Hudson, R.A. (1996). Sociolinguistics. Great Britain: Cambridge University Press.

Kartika et al. (2013). "Sikap Bahasa Masyarakat Jawa Barat terhadap Bahasa Daerah, Bahasa Indonesia, dan Bahasa Asing." Bandung.

Kartika et al. (2014). "Sikap Bahasa Pejabat Publik di Lingkungan Kementerian Pendidikan dan Kebudayaan Jawa Barat terhadap Bahasa Daerah, Bahasa Indonesia, dan Bahasa Asing." Bandung.

Kulsum, U. et al. (2015). Pengaruh Pengetahuan Peraturan Kebahasaan terhadap Sikap Bahasa Pengusaha/Pengembang Perumahan di Empat Kota dan Kabupaten di Jawa Barat. Bandung.

Landis, P.H. (1948). Pengantar Sosiologi Pedesaan dan Pertanian. Jakarta: PT Gramedia Pustaka Utama.

Martadiputra, B.A.P. (2016). "Penelitian Kuantitatif Sikap Bahasa". Makalah. Pelatihan Penelitian Kuantitatif Sikap Bahasa: Materi Statiska. Balai Bahasa Jawa Barat.

Peraturan Menteri Dalam Negeri Nomor 40 Tahun 2007.

Peraturan Presiden Republik Indonesia Nomor 16 Tahun 2010.

Peraturan Menteri Perdagangan Republik Indonesia Nomor 67/M-DAG/PER/11/2013.

Peraturan Pemerintah Republik Indonesia Nomor 57 Tahun 2014.

Ridwan, H.T.A. (2006). Bahasa dan Linguistik. Jakarta: Mestika.

Spolsky, B. (1998). Sociolinguistics. Oxford: Oxford University Press.

Sugiyono dan Sry Satria Tjatur Wisnu S. (2011). Sikap Masyarakat Indonesia terhadap Bahasanya. Yogyakarta: Elmatera Publishing.

Sugiyono (2010). Metode Penelitian Kuantitatif Kualitatif dan $R$ \& D. Bandung: Alfabeta.

Sustiyanti dan Rahayu, Ratih (2017). Pengaruh Pengetahuan tentang Peraturan Kebahasaan terhadap Sikap Bahasa Pengusaha Kuliner di Kabupaten Pringsewu. Jurnal Ranah, 6(1). DOI: https://doi.org/10.26499/rnh.v6i1.260

Undang-Undang Dasar Republik Indonesia 1945.

Undang-Undang Republik Indonesia Nomor 24 Tahun 2009.

Undang-Undang Nomor 6 Tahun 2014.

Undang-Undang Nomor 22 Tahun 1999.

Widi, Restu Kartiko (2010). Asas Metodologi Penelitian. Cet.1. Yogyakarta: Graha Ilmu. 
